\title{
IGNORING RULES OF SUCCESSION: HOW THE BOARD REACTS TO CEO ILLNESS ANNOUNCEMENTS
}

\author{
Wallace N. Davidson III \\ Southern Illinois University \\ Carbondale, IL \\ Shenghui Tong \\ Siena College \\ Loudonville, NY \\ Dan L. Worrell \\ University of Arkansas \\ Fayetteville, AR \\ Wei Rowe \\ University of Nebraska - Omaha \\ Omaha, NE
}

\begin{abstract}
Rules of behavior guide decisions, and succession rules guide CEO selection. When CEO tumover is unanticipated, succession rules may not be able to guide the board. We examine unanticipated successions that occur when a CEO becomes ill or injured. These unanticipated successions are associated with a greater likelihood of former-CEO successors than when the successions are anticipated. The stock market reacts positively to former-CEO succession announcements. While this type of succession may not be consistent with succession rules, it may be consistent with their functions by reducing internal conflict and allowing directors to maintain fiduciary responsibility.
\end{abstract}

Leadership is an important component of successful corporate governance. CEO succession has received considerable attention in the extant literature. Succession planning's importance may need to be given top priority by boards of directors (Shen \& Cannella, 2003).

Ocasio (1999) analyzed the succession process and the rules that govern it. He argued that rules of behavior exist throughout all areas of corporate activity providing regularity and structure to corporate decisions. The succession process provides an interesting case in which we can observe how boards rely on formal and informal rules to make decisions. There may be cases in which companies are unable to utilize succession rules because the need for succession is unanticipated and occurs suddenly. 
There are a number of ways in which unanticipated events could lead to the immediate need for succession. For example, a $\mathrm{CEO}$ could suddenly decide to quit the company leaving the board with an immediate succession decision. However, in these cases, it may not be possible to determine if it was the CEO's decision or a forced turnover. Alternately, a CEO could die while in office or become ill or injured. We examine unanticipated succession decisions following CEO illness/injury announcements rather than CEO death, because when a CEO dies there is no choice; the board must appoint a successor. However, when a CEO is ill or injured, the executive and board may have a choice. They can appoint a successor or depending on the severity of the affiction let the CEO attempt to continue. We examine both the successions that occur after injury or illness announcements and decisions to let the CEO continue in office.

The pressures and responsibilities of a senior executive combined with the age of most senior executives can lead to serious illness. What happens when a CEO becomes injured or ill and the affliction is serious? When would the board replace the afflicted CEO and who assumes the vacated positional responsibility? Unanticipated succession decisions may prohibit the board from relying on its normal rules of succession. Vancil (1987) defines several styles of internal succession including relay and horse-race successions. Each type of succession would have its own informal or formal rules guiding the process. What these succession types have in common are that the board promotes a successor CEO from a position below the CEO in the corporate hierarchy. In other successions, the CEO comes from outside the firm. For the purposes of this paper, we define normal succession to include both outside succession and successions in which the successor is promoted from below in the corporate hierarchy.

However, when the succession is unanticipated such as when an executive becomes ill, the board may not find the normal rules of succession to be useful. When an executive is unable to function, a successor may be needed to both run the company and show the outside stakeholders that someone is in charge. We propose that in unanticipated successions boards may appoint someone from the board such as the board chair or former $\mathrm{CEO}$. Such an appointment would likely show stakeholders that there will be continuity in company operations and that an experienced executive is in charge.

\section{Theoretical Background}

In this section, we examine rules of behavior and how they impact succession decisions. We then propose that companies will be more likely to violate these rules when there is a sudden and forced need for succession.

\section{Rules of Behavior}

Rules of behavior are integrated into all corporate activities and actions. Reliance on these informal or formal rules guides rational decision-making. Organizational rules guide rational choices by providing a framework or basis for decisions. 
People make decisions by evaluating alternatives and their consequences under the context of rules. Following rules suggests that corporate executives utilize a rational process or mechanism to make decisions. Following rules guide behavior and lead to an outcome, and they help to maintain organizational equilibrium. An organizational decision may be considered more appropriate if it does not violate the organization's rules that are appropriate to the situation, but decisions made that seemingly violate rules may be considered less appropriate and legitimate (March, 1994). Reliance on rules has been integrated into theories of the firm, and rules may help protect shareholder interests and help ensure organizational survival (Ocasio, 1999).

Rules of behavior serve at least three functions in an organization (Ocasio, 1999). First, rules provide a type of routine for programs of actions (March \& Simon, 1993). Here, rules guide the day to day business of the organization as well as provide routine solutions to the out-of-the ordinary decisions. Second, rules allow decision-makers to meet their responsibilities. Decision-makers are accountable for their actions and when decisions have been made based upon rules of behavior, they are easier to defend (Clark, 1991). In corporations, boards have a fiduciary responsibility to stakeholders, in general, and to shareholders, in particular. When board members rely on rules in their decisions, they can justify the decisions as rule-appropriate and more easily argue that the decision meets their fiduciary responsibilities. Third, following rules may lessen political conflict in corporations. Following rules signals the appropriateness of a decision and reduces the basis for conflicts (Nelson \& Winter, 1982).

\section{Rules of Behavior and Succession}

One of the major functions of a board of directors is the hiring and firing of senior managers such as the CEO. As such, $\mathrm{CEO}$ succession decisions are under the purview of the board. Presumably, the board will appoint who they believe is the best person to lead and run the company as well to as represent the company with various stakeholder groups. The board often decides when a CEO succession is to take place and who the successor will be. How boards make succession decisions and the process that board members follow has been the subject of considerable work.

Ocasio (1999) argues that rules of behavior guide the succession decision process. Different styles of succession in organizations lead to different rules of succession. Vancil (1987) defines several succession styles including relay succession and horse race succession. In relay successions an heir-apparent serves a training period and is groomed to become the new successor. At the appropriate time, the heir steps in and becomes the new CEO. The rules may be different in other styles of succession. For example, in a horse race succession, internal candidates compete for the top spot. This process has been described as an economic contest (Chan, 1996). The winner of the horse race assumes the CEO position. Zhang and Rajagopalan (2004) find that when there are a large number of internal candidates, the likelihood of relay succession decreases, and 
so a large number of potential candidates may increase the likelihood of a horse race style succession. Even though the internal rules vary for these different styles of succession, in both relay and horse race succession, the successor is promoted from a position below the CEO in the corporate hierarchy. Following rules may be more appropriate and more common in ordinary situations. For example, in normal anticipated succession decisions such as when a CEO retires, boards will often select internal successors who are chosen pursuant to the organization's rules (Kesnor $\&$ Sebora, 1994). Shen and Cannella (2003) document that the stock market reacts positively to succession when a designated heir-apparent becomes the successor CEO. Naveen (2000) finds similar results and shows that inside succession is more likely when the board adopts a formal succession plan.

Another type of succession occurs when the board hires an outsider. The hiring of an outsider would be inconsistent with a planned internal succession process. Chan (1996) argues that only when the need arises or when a clearly superior outside candidate is available would succession planning rules be violated and an outsider hired. Outside succession may occur when there is organizational stress, such as poor performance (Parrino, 1997; Cannella \& Lubatkin, 1993). During these times of stress, the company may need to show that it is changing directions and bringing in an outsider to initiate changes although the presence of a large proportion of inside directors on the board and a CEO with short tenure in the job may overcome the tendency to hire an outsider (Shen \& Cannella, 2002). While the presence of a large proportion of outsiders on boards makes the choice of an outside successor more likely in both normal successions and those following CEO dismissal (Borokhovich, Parrino \& Trapani, 1996). Succession rules may, therefore, be situationally determined and include various types of internal and external successions. In these cases, boards have had time to plan the succession process, influence the timing of the succession and choose the most suitable candidate.

We propose that following the rules of succession and utilizing the planned succession process may not be possible in situations requiring an immediate and unanticipated succession. In an unanticipated succession, the rules may need to be adapted or ignored when there is need for immediate board action in maintaining a leadership structure for the firm. For relay succession to take place, a previously, designated and appropriately trained heir-apparent is necessary. In a horse race, there needs to be ample time for "one horse to take the lead". To hire an outsider requires time to develop a slate of suitable candidates and to evaluate their potential. When the succession is unanticipated, it may not be possible to follow the normal rules of succession for either an internal or an external search. When there is an immediate and unanticipated need for a successor, the board may look to a candidate with the experience and knowledge to step into the position and assume the reins of command. Here it may be that the board will appoint a former CEO or the board chair to take over the corporation's leadership. This type of succession may be more consistent with the three functions of rules even though it does not follow the normal rules of succession. 
Rules function to permit routine decisions. History and precedence guide rules under ambiguity (Zucker, 1977), and a sudden and unanticipated succession will produce this ambiguity. By hiring a former CEO or board member with top executive experience, the routine of the company can continue and ambiguity will likely lessen. If a designated heir is adequately prepared or if the horse race is far enough along to have produced a clear leader, then the board may be able to follow the normal succession rules and promote the candidate. Hiring an heir-apparent that is possibly inadequately trained or selecting the horse race winner when the race is not complete could actually increase the perceived ambiguity, but hiring the former CEO whose record is known should serve to reduce the ambiguity.

Following rules may help decision makers to meet fiduciary responsibility. In a sudden succession, when the normal rules of succession are not appropriate, hiring a former $\mathrm{CEO}$ or the board chair may be the lower risk choice that serves to allow the board to meet its fiduciary responsibility. Selecting the possibly under-trained heir-apparent in relay succession or the horse race winner of the unfinished horse race may not be perceived as the appropriate decision and as a possible violation of the board's fiduciary responsibility.

Following rules lessens potential for conflict. In an unfinished horse race the successor to a sudden succession may engender bitterness in the losers. Bitterness can lead to internal political conflict. An heir-apparent that is perceived to be under trained could also cause internal political strife. On the other hand, in these sudden and unanticipated successions, hiring the former CEO or chair to be the successor could lessen the potential for internal political conflict.

One type of unanticipated decision that may require an immediate succession decision is when a top executive falls seriously ill or receives major injuries in an accident. Here, the board must decide whether to replace the ill executive or to allow them to continue in their position. Certainly the severity of the illness or injury will influence the decision. However, there may be other considerations such as the impact of the decision on the company's stakeholders.

An immediate or at least timely decision may be needed so the normal rules of succession may not apply. In the crisis, the reappointment of a former CEO may seem the most prudent decision. The familiar face may reduce anxiety in the financial, product and supply markets as well as within the organization and provide the perception of continuity. We, therefore, propose:

Hypothesis 1: In situations requiring unanticipated and immediate succession such as when the CEO becomes ill or injured, rather than following a planned succession process that is consistent with normal rules of succession, the board will more likely select a former CEO or board chair than when the succession is likely anticipated.

\section{CEO Authority and Unanticipated Successions}

Dual leaders, those that are both CEO and Chair, are considered by some to be unambiguous leaders providing unity of command and authority over the firm 
(Massie, 1965). A leader that is unambiguous may help a company to obtain resources in the market place (Andrews, 1971: Finkelstein \& D'Aveni, 1994). Social choice theory suggests that problems may occur when authority is divided between people (e.g. separate CEO and Chair) making it difficult to pinpoint causes of problems (Arrow, 1963; Sen, 1970) and causing intra-company asymmetric information problems (Brickley, Coles \& Jarrell, 1997).

When such an unambiguous leader is not able to continue in their role because the executive has fallen ill, they may choose to give up various duties that can lessen their authority and ultimately reduce the benefits derived from this leadership style. However, giving up authority and stepping aside may be unpalatable to the dual executive for several reasons so the dual executive may stay in the position until he/she can no longer physically perform their duties. First, giving up authority may reduce the executive's self-perceived personal power. By allowing someone to take over even part of his or her duties, the executive shows weakness. Second, giving up authority may lessen the appearance of having an unambiguous leader to stakeholders and reduce the benefits that this leadership style conveys. Third, when a CEO is also Chair, the executive is less likely to be fired by the board even when performance is poor (Goyal \& Park, 2002) because the dual position gives the executive greater power. Even when ill, the dual $\mathrm{CEO} / \mathrm{Chair}$ will likely have more clout with the board and would be less likely to be forced out. Therefore, a dual CEO/Chair will be more likely to attempt to maintain their positions and remain in power when ill or injured than under a non-dual leadership structure.

By maintaining his or her dual positions, the dual CEO/Chair allows the functions of rules to be maintained. This decision will allow the normal routine to be followed. The board can argue that keeping the unambiguous leader serves shareholder interests and that they have maintained their fiduciary responsibility and lessened the possibility of internal strife and political problems caused by an unanticipated succession.

Certainly, the severity of the injury or illness will influence whether an executive steps aside. Some illnesses/injuries may leave an executive physically unable to perform while in other cases, the board and executive will need to decide if the executive can continue to function in their position or to give the appearance that they are functioning. We, therefore, propose:

Hypothesis 2: In situations requiring possible immediate and unanticipated succession such as when an executive becomes ill or injured, a dual $C E O / C h a i r$ will more likely retain their position than will a non-dual $C E O$ even when controlling for the severity of the affliction.

\section{Stock Market Reaction}

Worrell, Davidson, Chandy, and Garrison (1986) find that the stock market reacts negatively to sudden death announcements of CEOs. Here, a non-routine turnover has occurred and the organization must adapt. Worrell and Davidson 
(1987) find that following the CEO death, when an insider is appointed, there is an offsetting positive stock market reaction. Placing an insider into the deceased executive's position may signal the market that the company is continuing to rely on rules to guide them. By relying on the rules, the corporation has signaled the market that the situation is under control, and the market responds positively. Putting an experienced leader in the position will avoid the appearance or reality of promoting the heir-apparent before they are ready.

Shen and Cannella (2003) find that the market reacts positively to news of a relay succession process. Here, the stock market reinforces the reliance on rules by reacting positively to the announcements that indicates that rules of succession have been followed. In other words, by signaling that normal rules of succession have been followed, the company shows that the situation is under control. Naveen (2000) argues that firms manage the succession process to minimize the succession and transition costs. When there is a non-normal succession requiring immediate board action, such as when a CEO becomes ill, it may be less costly to hire the former $\mathrm{CEO}$ or board chair. There would likely be less disruption since the former CEO's style is known. We, therefore, propose that the stock market will reward the company for decisions that may violate the normal rules of succession but that are consistent with the functions of the rules. Therefore:

\section{Hypothesis 3: The stock market will react more positively to unanticipated succession announcements, such as when a CEO becomes ill or injured, when a former CEO or the chair assumes the CEO position.}

\section{Method}

In this paper, we examined the succession process in corporations when the CEO or Chair becomes ill or injured. By examining CEO illness/injury rather than other causes of unanticipated succession, we examined situations when the board had the choice to name a successor or not. We also examined the stock market reaction to the succession announcements to determine how the stock market views board of director response to the injury/illness announcement.

\section{Sample}

We located our sample by performing a key word search in news reports in Lexis-Nexis. We developed several key word strings such as executive and CEO combined with words such as illness, sickness, injury, cancer, heart disease, etc. From this search, we were able to find 113 stories which indicated that a CEO or Chair had become ill or injured over the years 1992 to 2002. We then obtained the news stories that contained the announcements and were able to find the required information (see below) for 105 announcements. These 105 announcements became our final sample. We used the All News files on Lexis Nexis to ensure that the news announcement is the first story. There was often a delay in reporting an executive's illness. In our sample, seventy-nine percent of the 
companies made the announcement within one week of the executive becoming ill. Ninety percent of the companies made the announcement within one month of the illness's onset and ninety-five percent within 90 days. There were three companies that waited at least one year to make an announcement.

Table 1

Sample Characteristics

\begin{tabular}{|c|c|c|c|c|c|c|}
\hline \multirow[t]{6}{*}{ Title of Ill Executive: } & \multicolumn{3}{|c|}{ CEO } & 6 & $5.7 \%$ & \\
\hline & \multicolumn{3}{|c|}{ CEO \& President } & 11 & $10.5 \%$ & \\
\hline & \multicolumn{3}{|c|}{ CEO \& Chair } & 53 & $50.5 \%$ & \\
\hline & \multicolumn{3}{|c|}{ CEO, Chair \& President } & 19 & $18.1 \%$ & \\
\hline & \multicolumn{3}{|c|}{ Chair } & 16 & $15.2 \%$ & \\
\hline & \multicolumn{3}{|c|}{ Total } & 105 & $100.0 \%$ & \\
\hline \multirow[t]{5}{*}{ Type of replacement: } & \multicolumn{3}{|c|}{ No Replacement } & 33 & $31.4 \%$ & \\
\hline & \multicolumn{3}{|c|}{ Inside Executive (heir) } & 54 & $51.4 \%$ & \\
\hline & \multicolumn{3}{|c|}{ Chair or Board Member } & 18 & $17.2 \%$ & \\
\hline & \multicolumn{3}{|c|}{ Total } & 105 & $100.0 \%$ & \\
\hline & CEO & $\begin{array}{c}\text { CEO \& } \\
\text { President }\end{array}$ & $\begin{array}{c}\text { CEO \& } \\
\text { Chair }\end{array}$ & $\begin{array}{l}\text { CEO, Chair } \\
\text { \& President }\end{array}$ & t Chair & Total \\
\hline No Replacement & 1 & 1 & 18 & 9 & 4 & 33 \\
\hline Inside Replacement & 4 & 7 & 29 & 7 & 7 & 54 \\
\hline \multicolumn{7}{|l|}{ Chair or Board Member } \\
\hline Replacement & 1 & $\underline{3}$ & $\underline{6}$ & $\underline{3}$ & $\ldots$ & $\underline{18}$ \\
\hline Total & 6 & 11 & 53 & 19 & 16 & 105 \\
\hline
\end{tabular}

Permanent Replacement": 44 of the $72(61.1 \%)$ replacements

\begin{tabular}{|c|c|c|c|}
\hline \multirow[t]{3}{*}{ Illness: } & Not Life-Threatening & 36 & $34.3 \%$ \\
\hline & Potentially Life Threatening & 69 & $65.7 \%$ \\
\hline & Total & 105 & $100.0 \%$ \\
\hline
\end{tabular}

\footnotetext{
a The proportion of potentially life-threatening illnesses did not vary between the temporary and permanent replacement sub samples.
}

From the news stories we obtained several pieces of information. This data is summarized in Table 1. Table 1 also shows the titles of the ill executives. There are 6 CEOs, 11 CEOs \& Presidents, 53 CEOs \& Chairs, 19 CEOs, Presidents 
$\&$ Chairs, and 16 Chairs. The table also contains information on the type of replacement. In 33 cases, the executive was not replaced. In 54 cases, the executive was replaced by another inside executive such as the President, Chief Operating Officer, or a Vice President. These successors were most likely heir-apparent for the CEO. In 18 cases the ill executive was replaced by the Chair of the Board or other board member that was a retired CEO of the company with continued presence on the board. It is important to note that in our sample of unanticipated successions, the boards appointed no outside candidates. The next section of Table 1 shows the type of replacement divided by executive title. We will utilize this information later.

We also found that 44 of the 72 replaced executives were permanent replacements and 28 were only temporary. We based this designation on the wording in the news stories and assumed a succession was permanent unless the news story specifically states that it was temporary.

We designated an illness as life threatening if the news story indicated that it was, or designated it as not life threatening if the news story specifically said it was not. In addition, if the news story made no such indication, we classified heart problems and cancer as potentially life threatening. We found no statistical difference in the types of replacement by whether or not the illness was life threatening or by any measure of type of illness.

To test Hypotheses 1 we compared the successor types in our sample of CEO illness announcements to normal succession types resulting from other than sickness or death. We, therefore, needed a comparison group of succession announcements that occur for other reasons. We developed two separate control samples. For the first control sample, we identified 1017 CEO successions and the year of the succession from the Execucomp data base. We then searched news stories and proxy statements for each of the successions and ensured that they did not result from illness, injury, or death of the predecessor and to determine the successor type. We were able to obtain complete information for anticipated 738 successions. This first control sample allowed us to compare our sample of illness/injury related successions to a large number of successions unrelated to illness/injury of the predecessor.

For our second control sample, we identified the primary four digit SIC code of each sample firm. Using COMPUSTAT, we identified other firms with the same four digit SIC codes. We then determined the firm from this list that was closest in size (based on total assets) to the sample firm. The firms that we identified with this matching procedure were the industry matched control firms. For each of these firms, we determined the origin of the most recent CEO succession.

\section{Statistical Method}

To determine how the stock market reacts to the news announcements, we used standard event methodology (Fama, Fisher, Jensen \& Roll, 1969). As this method is well known and commonly utilized in research, we only summarize our procedure here. We defined day 0 as the date the news story first appears in the press. 
To estimate normal stock returns, we estimated the market model for each firm using days -290 to -90 relative to the announcement date, day 0 . The market model was a regression with the company's daily stock returns as the dependent variable and the equally weighted market index as the proxy for the market's returns and as the independent variable. We then applied the estimated regression parameters from the market model to the actual daily stock market returns on days $-1,0$ and 1. This computation produces the security's normal (or expected) stock return. The normal return would be the return that is expected for the company given the overall movement of the market and the security's risk. We compare the normal returns to the actual returns to produce the abnormal returns. In the absence of information that impacts a company's value, abnormal returns are expected to be zero. We utilize $t$-statistics to determine if the abnormal returns are non-zero.

\section{Results}

\section{Replacement of III Executives}

Table 2 contains frequency analyses and comparisons for the replacement decisions of top executives. In Panel A we test Hypothesis 1. Here, we show that in our sample there are 60 executives with the title of CEO that become ill/injured and do not retain their position. We have, therefore, eliminated the $33 \mathrm{ill}$ or injured executives that retained their position. We also eliminate the 16 executives with the Chair title (four executives are in both eliminated sub samples leaving $60 \mathrm{ill} /$ injured CEOs. We obtain the sub sample of 60 as follows: $105-33-16$ $+4=60)$. There are $47(78.3 \%)$ replacements with another inside executive (President/COO/Vice Presidents), but there are $13(21.7 \%)$ that are replaced by the Chair or another board member (former CEO).

To test Hypothesis 1, we need to determine if the frequency of Chair or other board member successors is greater than normally occurs. We first compare our sample to the anticipated succession control sample. In our sample, 47 of the $60(78.3 \%)$ unanticipated succession are inside executives while $13(21.7 \%)$ are the Chair or a board member. From the 738 anticipated successions, 50 $(6.7 \%)$ are replaced by board members including the Chair (25), former Chair (5) or Vice-Chair (20). If our sample firm successions behaved as those in the control sample, 56 of the 60 sample firms $(93.3 \%)$ would be an insider and only four would be the Chair or other board member. We define these numbers to be the expected frequency for our sample and compare the actual frequency to the expected frequency. The resulting chi-square is 21.70 and is significant at better than the 0.001 level. This evidence is consistent with Hypothesis 1. When a CEO becomes ill, the board will bypass the normal rules of succession more often than if the succession had been anticipated. Here, the board selects an experienced executive such as the board chair or board member that is a former CEO.

We next compare the frequencies from our sample firms to the industry matched control sample. In the industry matched control sample, 54 (90\%) of the 60 successors are either insiders promoted from below or are outsiders. Only six $(10 \%)$ 
Table 2

Analysis of Replacement Decisions When an Executive Becomes Ill

Panel A: Comparison to Anticipated Succession Sample (Excludes Chair-Only IIl Executives) Sample Firms Anticipated Succession Sample

\begin{tabular}{|c|c|c|c|c|c|c|c|c|}
\hline & \multicolumn{2}{|c|}{ Sample Firms } & \multicolumn{3}{|c|}{ Anticipated Succession Sample } & \multicolumn{3}{|c|}{ Industry Matched Sample } \\
\hline & Frequency & Percent & Frequency & Percent & $\begin{array}{c}\text { Expected } \\
\text { Frequency }\end{array}$ & Frequency & Percent & $\begin{array}{l}\text { Expected } \\
\text { Frequency }\end{array}$ \\
\hline Inside Executive & 47 & $78.3 \%$ & 688 & $93.3 \%$ & 56.0 & 54 & $90.0 \%$ & 54.0 \\
\hline Chair or Board Member & $\underline{13}$ & $21.7 \%$ & 50 & $6.7 \%$ & 4.0 & 6 & $10.0 \%$ & 6.0 \\
\hline Total Test Statistic & 60 & $100.0 \%$ & 738 & $100.0 \%$ & $\begin{aligned} & 60.0 \\
X^{2}= & 21.70^{* * *}\end{aligned}$ & 60 & $100.0 \%$ & $\begin{array}{c}60.0 \\
X^{2}=9.1^{* *}\end{array}$ \\
\hline
\end{tabular}

Panel B: Comparison of Permanent Replacements to Anticipated Successions (Excludes Chair-only Ill Executives)

\section{Permanent Replacement Anticipated Succession Sample Matched Sample}

Inside Executive

Chair or Board Member

Total Test Statistic

\begin{tabular}{cccccccc} 
Frequency & Percent & Frequency & Percent & $\begin{array}{c}\text { Expected } \\
\text { Frequency }\end{array}$ & Frequency & Percent & $\begin{array}{c}\text { Expected } \\
\text { Frequency }\end{array}$ \\
\hline 28 & $72.7 \%$ & 688 & $93.3 \%$ & 33.6 & 32 & $90.0 \%$ & 32.0 \\
$\frac{8}{36}$ & $\underline{27.3 \%}$ & $\frac{50}{738}$ & $\frac{6.7 \%}{100.0 \%}$ & $\frac{2.4}{36.0}$ & $\frac{4}{36}$ & $\frac{10.0 \%}{100.0 \%}$ & $\frac{4.0}{36.0}$ \\
& $100.0 \%$ & & & $\mathrm{X}^{2}=13.9 * * *$ & & & $\mathrm{X}^{2}=4.5^{*}$
\end{tabular}


Table 2 continued

Analysis of Replacement Decisions When an Executive Becomes Ill

\begin{tabular}{|c|c|c|c|c|c|c|c|c|}
\hline \multirow[t]{3}{*}{ Panel C: Comparison } & mporary Re & cements to & nticipated $\mathbf{S}$ & essions ( $E$ & ludes Chair & ly III Exe & & \\
\hline & \multicolumn{2}{|c|}{ Temporary Replacement } & \multicolumn{3}{|c|}{ Anticipated Succession Sample } & \multicolumn{3}{|c|}{ Matched Sample } \\
\hline & Frequency & Percent & Frequency & Percent & $\begin{array}{c}\text { Expected } \\
\text { Frequency }\end{array}$ & Frequency & Percent & $\begin{array}{c}\text { Expected } \\
\text { Frequency }\end{array}$ \\
\hline Inside Executive & 19 & $79.2 \%$ & 688 & $93.3 \%$ & 26.1 & 22 & $90.0 \%$ & 22.0 \\
\hline Chair or Board Member & 5 & $20.8 \%$ & 50 & $6.7 \%$ & 1.9 & $\underline{2}$ & $10.0 \%$ & 2.0 \\
\hline \multirow[t]{2}{*}{ Total Test Statistic } & 24 & $100.0 \%$ & 738 & $100.0 \%$ & 24 & 24 & $100.0 \%$ & 24.0 \\
\hline & & & & & $X^{2}=9.7 * *$ & & & $X^{2}=3.3 \dagger$ \\
\hline
\end{tabular}

Panel D: Replacement Comparison by Dual versus Non-Dual Executiveb

\begin{tabular}{llccc} 
Executive Title & Stays/Replaced & Frequency & Percent & Expected Frequency \\
\hline CEO or CEO \& President & Stays in Position & 2 & $11.8 \%$ & na \\
& Replaced & $\underline{15}$ & $\underline{88.2 \%}$ & na \\
& Total & 17 & $100.0 \%$ & \\
CEO \& Chair plus & Stays in Position & 27 & $37.5 \%$ & 8.5 \\
CEO, Chair \& President & Replaced & $\underline{45}$ & $\underline{62.5 \%}$ & $\underline{63.5}$ \\
& Total & 72 & $100.0 \%$ & 72.0
\end{tabular}

${ }^{\mathrm{a}}$ We also compared our sample firms to the sample in Nemec (1995). Her sample of 124 inside CEO successions includes 122 successions of inside executives and only 3 cases of the chair or former CEO taking the CEO position. Using her sample as the expected frequency and comparing our sample to this expected frequency produced a chi-square of 146.4 which is significant at the 0.001 level. Our sample produces a significantly greater number of cases in which a former $\mathrm{CEO}$ or board chair assumes the CEO position than when compared to her sample.

${ }^{b}$ We find no statistical difference in the number of life-threatening illnesses/injury based on executive title or duality. ${ }^{* * *} \mathrm{p}<0.001,{ }^{* *} \mathrm{p}<0.01,{ }^{*} \mathrm{p}<0.05, \dagger \mathrm{p}<0.10$ 
are former CEOs or the board chair. We define these frequencies from the control sample to be the expected frequency for our sample and compare the expected frequency to the actual frequency. The resulting chi-square statistic is 9.1 (significant at 0.01 ). This evidence is consistent with Hypothesis 1; the frequency of successions of former CEOs and board chairs is greater following CEO illness/injury announcements than occurs from either of our control samples.

It is possible that the successor CEOs not promoted in the normal fashion would be temporary successors. To examine this issue, in Panel B, we repeat the tests for the 36 permanent succession appointments from the sample. When we compare the actual frequency from our sample ( 28 normal successions, 8 former $\mathrm{CEO} / \mathrm{chairs}$ ) to the expected frequency from our anticipated succession control sample, the chi-square is 13.9 (significant at 0.001 ). When we compare the sample frequency to the industry matched control sample, the chi-square is 4.5 (significant at 0.05 ). The evidence for permanent successions is consistent with the predictions of Hypothesis 1.

In Panel $\mathrm{C}$, we compare the frequency of the normal successions from our sample to the frequency from the anticipated succession control sample (chisquare is 9.7 , significant at 0.01 ) and to the industry matched control sample (chi-square is 3.3 , significant at 0.10 ). These results for temporary succession announcements are consistent with the predictions of Hypothesis 1. Thus, the temporary/permanent nature of the succession announcements does not qualitatively change our findings.

In Panel D, we show the comparison of CEO successions following sickness announcements for executives in a dual position (CEO \& Chair, and CEO, Chair \& President) and those not in a dual position (CEO or CEO plus President). Here, we test Hypothesis 2 and show the comparison based on whether the ill executives stay in their positions versus when they do not. When a sick executive is in a non-dual position, two of the $17(11.8 \%)$ remain in their positions. For the executives in the dual positions, 27 of the $72(37.5 \%)$ retain their positions. If the dual executives stayed in their positions in the same proportion as the non-dual executives, 8.5 would have stayed and 63.5 would not have. We can compare the actual occurrence to the expected occurrence with a chi-square test. The chi-square is 45.65 and is significant at 0.001 . These results are consistent with $\mathrm{H}_{2}$. We find a greater incidence of dual executives retaining their positions than do non-dual CEOs. These results could be driven by dual executives having less-severe illnesses or injuries. Based on our designation of life-threatening, we cannot find evidence that the severity of the affliction is related to the executives' titles. Of the 17 non-dual CEOs, $6(35.3 \%)$ had non-life-threatening afflictions while 11 $(64.7 \%)$ had life-threatening problems. For the 72 dual executives $23(31.9 \%$ had non-life-threatening afflictions while $49(68.1 \%)$ had life-threatening problems.

\section{Market Reaction to Unanticipated Succession Announcements}

In Table 3, we show the abnormal returns for days $-1,0$, and 1 . The first column shows the results for the total sample. All three day's abnormal returns 
are nominally negative, but only day 0 , the announcement day, has a significant abnormal return (marginally significant at the 0.10 level).

Table 3

Cumulative Abnormal Returns

\begin{tabular}{cccccc}
\hline & \multicolumn{5}{c}{ Who Replaces Executive } \\
\cline { 2 - 6 } Day & $\begin{array}{c}\text { Total } \\
\text { Sample }\end{array}$ & $\begin{array}{c}\text { Executive Stays } \\
\text { in Position }\end{array}$ & $\begin{array}{c}\text { Inside } \\
\text { Executive }\end{array}$ & $\begin{array}{c}\text { Chair or } \\
\text { Director }\end{array}$ & $\begin{array}{c}\text { ANOVA } \\
\text { F-Statistic }\end{array}$ \\
\hline \multirow{2}{*}{1} & -0.0010 & -0.0010 & 0.0101 & -0.0042 & 1.32 \\
& $(-0.20)$ & $(-0.20)$ & $(1.13)$ & $(-0.73)$ & \\
\multirow{2}{*}{0} & -0.0056 & -0.0063 & -0.0136 & 0.0175 & $6.68^{* *}$ \\
& $(-1.70) \dagger$ & $(-1.68) \dagger$ & $(-3.10)^{* *}$ & $(1.75) \dagger$ & \\
\multirow{2}{*}{1} & -0.0027 & -0.0197 & 0.0019 & 0.0137 & 1.72 \\
& $(-0.41)$ & $(-1.09)$ & $(0.39)$ & $(0.98)$ & \\
\hline
\end{tabular}

$* * p<0.01$

$+\mathrm{p}<0.10$

In the next three columns, we divide the sample based on the replacement decision. When the ill executive stays in their position, the day 0 abnormal return is negative and only marginally significant (at the 0.10 level). When the board selects an inside candidate, the abnormal return is negative and significant (at the 0.01 level). However, when the board replaces the ill executive with the Chair or board member (usually a former CEO) the abnormal return is positive and only marginally significant (at the 0.10 level). We compare these means using an ANOVA test. The value of $F$ on day 0 is 6.68 , and it is significant at 0.01 . The market reacts negatively when the executive stays in their position or when an inside executive replaces the ill CEO and positively when a more experienced executive takes the corporate reigns, and the difference in the day zero abnormal returns is highly significant.

We also compare the market reaction to the types of successors with regression analysis. This approach allows us to compare the market reactions to the succession decisions while controlling for other factors that may influence the market reaction. We control for the number of delays in announcing the illness, whether the succession is permanent or temporary, and whether the illness is life-threatening or not. Finally, we control for the ill executive's title. We classify title in a manner similar to the "CEO Power Curve" in Vancil (1987, p. 225). We classify a CEO as 1 , a CEO \& President as 2, CEO \& Chair as 3, CEO, Chair \& President as 4, and a Chair as 5. We also experimented with other title classifications such as whether the executive served in a dual capacity or not, but this did not materially influence the results. Panel A of Table 4 contains a correlation matrix of the control variables, test variable and the dependent variable. 
Table 4

Correlations and Regressions

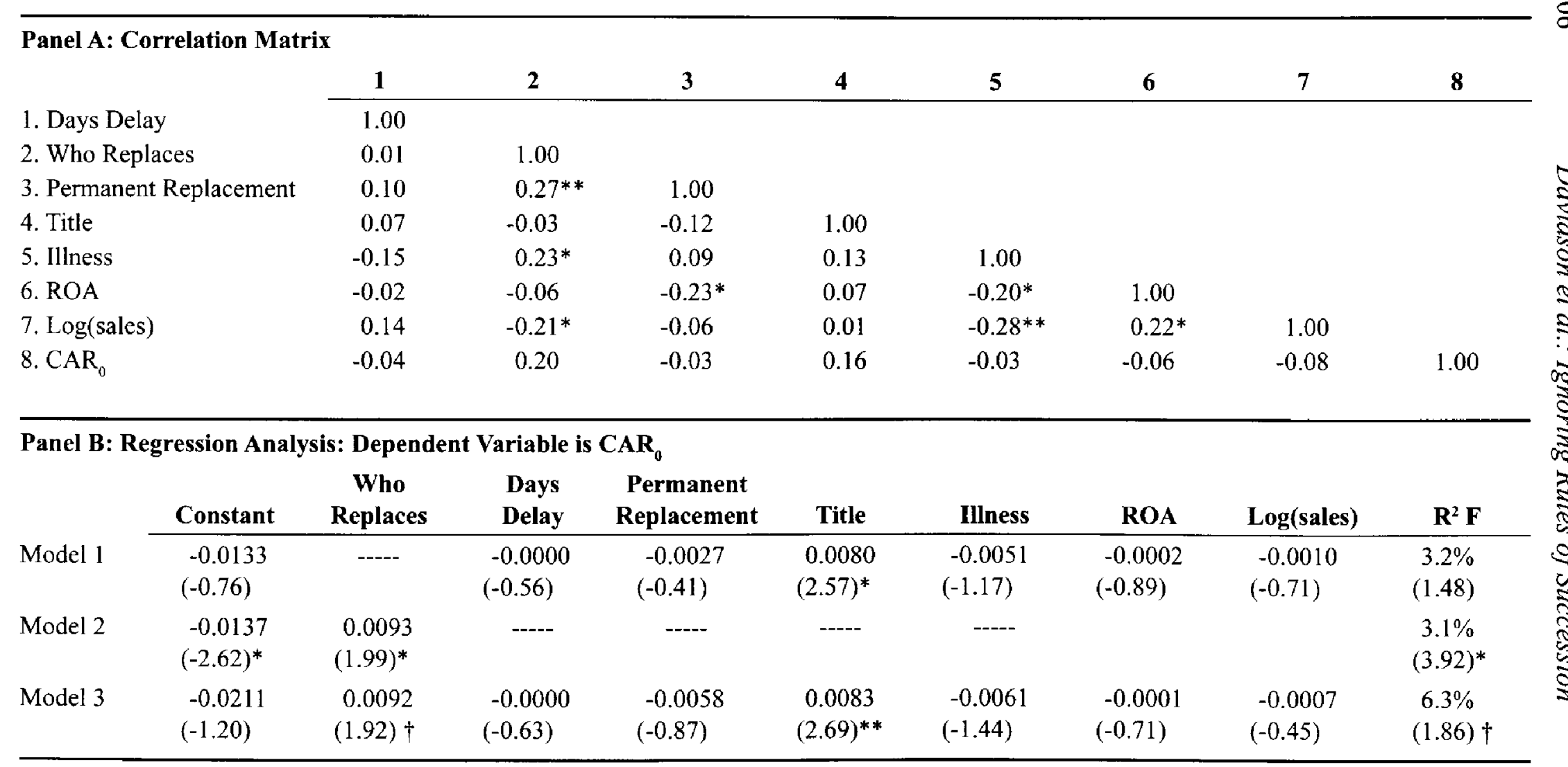

${ }^{* *} \mathrm{p}<0.01,{ }^{*} \mathrm{p}<0.05, \dagger \mathrm{p}<0.10$ 
Panel B of Table 4 presents the regression analysis with the day 0 CAR as the dependent variable. Model 1 estimates the relation between the dependent variable, $\mathrm{CAR}_{0}$, and the control variables. Only the estimated coefficient for title has even a marginally significant coefficient (significant at 0.10 ). In Model 2, we present the regression results for our test variable, "who replaces". We code this variable as 0 if the board does not replace the ill executive, 1 if an inside (heir-apparent) executive is the successor, and 2 if it is the chair or other board member. The estimated coefficient of this variable is significant at the $5 \%$ level. This result suggests that the market reacts more positively to an experienced executive taking the job and less positively when the ill executive is not replaced.

In Model, 3, we include the test variable and control variables. The estimated coefficient for who replaces is positive and significant at the 5\% level. Even after adding the control variables to the model, the results from Model 2 hold. These results are consistent with Hypothesis 3 .

\section{Summary and Conclusions}

\section{Findings}

We hypothesize and document that in times when an immediate succession decision is needed because a key executive becomes ill, the normal rules of succession are not always followed and must be adapted to the situation. None of the boards in our sample selected an outside candidate as successor. In addition, we find that when CEOs become ill that they are more likely replaced by a board member that is a former CEO than would be the case under more normal succession decisions. That is, the heir-apparent and horse-race succession processes are less likely to occur than in ordinary circumstances because the CEO's illness makes an immediate decision necessary. The decision to bring back a former CEO can be consistent with the functions of rules. This decision may allow for continued routine operations to continue, allow board members to give the appearance that they have met their fiduciary responsibility and may lessen internal political conflict if the heir-apparent has not been designated or is not ready to fulfill the responsibilities of the CEO position.

Our results also show that some CEOs retain their job after announcing their illness. The retention of their position is more likely to occur if the CEO is also the board chair. In these cases, the dual executive may have the power and clout with the board to retain their positions. Or, since the executive is in a dual position, there may not be anyone else on the board with the required experience so the dual executive must continue in the position. This also appears to be consistent with the functions of rules since quickly finding a replacement for both the chair and CEO could be both difficult and lead to outcomes that are inconsistent with the functions of rules.

Finally, we find results that are inconsistent with those in other research (Shen \& Cannella, 2003). They document that when an heir-apparent succession occurs that the stock market responds positively. We find that the market responds 
more positively when a former CEO and board member assumes the ill or injured CEO's position. This difference appears to be related to the maintenance of the rules and their functions. In the ordinary succession process, the heir-apparent assumes the CEO position and the market responds positively to a board action that is consistent with the normal rules of succession (Shen \& Cannella, 2003). In our sample, the normal succession process that would be consistent with succession rules may not be applicable. The immediacy and urgency of the succession decision and the market reaction we find suggest that the market responds positively to a board decision that is consistent with the functions of the rules. In both the Shen and Cannella (2003) study and here, the market responds to decisions that are consistent with the functions of rules. The non-normal situations require different decisions.

\section{Contributions}

\section{Theoretical Contributions}

We provide new insights into the theories of choice, board succession decisions and how rules of succession are employed or ignored in special circumstances. Rules become part of an organization's culture, and rules of succession are the rules that guide the board in making succession decisions. While the normal rules may be the appointment of an heir-apparent or the appointment of the winner of a horse race, we argue that when an immediate and unanticipated turnover occurs that the normal rules of succession are not applicable.

When such a situation occurs the board is faced with a potential dilemma. Board members must create new rules or adapt the old ones to have an outcome that is consistent with the functions of the rules. Rules are designed to help maintain routine, help decision-makers meet their responsibilities, and lessen internal conflict. Boards must make an immediate decision that at least maintains the functions of the rules. The succession decision must, therefore, allow for the continued operations of the company to be maintained, must allow the board to meet its fiduciary responsibilities or at least give this appearance, and not cause unnecessary internal conflict.

\section{Contributions to Practice}

Our results also have practical implications. They suggest that there is a need for succession planning. A recent Wall Street Journal article argues that finding a CEO on short notice is very difficult for a board and that corporations must prepare for the possibility that "they will be left unexpectedly without a leader" (Carey \& Ogden, 2000, p. A22). This same article points out that few companies prepare adequately for succession. This lack of succession planning occurs because current CEOs, for various reasons, hesitate to appoint and groom a successor. The positive stock market reaction to heir-apparent successions found by Shen and Cannella (2003) suggests that the financial marketplace rewards companies that do make and execute succession plans. The negative 
reaction that we find to inside executives replacing an ill or injured $\mathrm{CEO}$ and the large incidence of former CEOs replacing an ill or injured CEO, suggests that the market does not believe these companies to have adequately prepared internal successors.

The need for an experienced replacement has been documented in Bigley and Wiersema (2002). They argue that when heir-apparent successors have had more experience in the president or COO position, that they are more effective at generating strategic change. Since our results show that following CEO illness announcements that an heir is often not appointed, we interpret this to imply that either the heir has not been adequately trained and prepared for the CEO position or that the board is afraid that the outsiders to the company would perceive this to be the case. Rehiring a former CEO puts an experienced executive in the position and may help to ensure the marketplace that the business will continue as usual.

Our results, therefore, suggest that the board of directors must manage the succession planning process. This process is an on-going and continual process in which successors must be groomed. Boards must also have plans in place so that when a sudden and unexpected need for succession occurs they are prepared.

\section{Limitations and Future Research}

Others have documented that in non-normal situations that the normal rules of succession may be violated such as following poor performance and CEO dismissal (Kesnor \& Sebora, 1994) and following CEO death (Worrell \& Davidson, 1987). We have documented an additional situation in which the normal rules are not generally applied. However, our findings may not be generalized to other types of unanticipated succession. Future research on this issue is needed.

Another limitation of our findings is that we were not privileged to the medical records of the ill CEOs. We relied on the public announcements to determine the severity of the illness or injury. Based on the news reports, the severity or type of illness/injury did not seem to influence our results. If better information on the severity of the illnesses and injuries can become available, future research may be needed to measure how the severity of the incident impacts our results.

\section{References}

Andrews, K. R. (1971). The concept of corporate strategy. Homewood, IL: Irwin.

Arrow, K. J. (1963). Social choice and individual values. New York: Wiley Publishers.

Bigley, B. A., \& Wiersema, M. F. (2002). New CEOs and corporate strategic refocusing: How experience as heir apparent influences the use of power. Administrative Science Quarterly, 47, 707-727.

Borokhovich, K. A., Parrino, R., \& Trapani, P. (1996). Outside directors and CEO selection. Journal of Financial and Quantitative Analysis, 31, 337-355. 
Brickley, J. A., Coles, J. L., \& Jarrell, G. (1997). Leadership structure: Separating the CEO and chairman of the board. Journal of Corporate Finance, 3, 189-220.

Cannella, A. A. Jr., \& Lubatkin, M. H. (1993). Succession as a sociopolitical process. Academy of Management Journal, 36, 763-793.

Carey, D. C., \& Ogden, D. (2000, July 31). What if your CEO gets promoted to VP? Wall Street Journal, pp. A22.

Chan, W. (1996). External recruitment versus internal promotion. Journal of Labor Economics, 14, 555-570.

Clark, R. C. 1991. Agency costs versus fiduciary duties. In J. W. Pratt \& R. J. Zeckhauser (Eds.), Principles and agents: The structure of business. (pp. 55-79). Boston: Harvard Business School Press.

Fama, E. F., Fisher, L., Jensen, M. C., \& Roll, R. (1969). The adjustment of stock prices to new information. International Economic Review, 10, 1-21.

Finkelstein, S., \& D'Aveni, R. A. (1994). CEO duality as a double-edge sword: How boards of directors balance entrenchment avoidance and unity of command. Academy of Management Journal, 37, 1079-1108.

Goyal, V. K., \& Park, C. W. (2002), Board leadership structure and CEO turnover. Journal of Corporate Finance, $8,49-66$.

Kesnor, I. F., \& Sebora, T. C. (1994). Executive succession: Past, present \& future. Journal of Management, $20,327-372$.

March, J. G. (1994). A primer an decision making: How decisions happen. New York: Free Press.

March, J. G., \& Simon, H. A. (1993). Organizations (2nd ed). Cambridge, MA: Blackwell Business.

Massie, J. L. (1965). Management theory. In J. G. March (Ed.). Handbook of organizations. (pp. 387-422). Chicago: Rand-McNally.

Naveen, L. (2000). Management turnover and succession planning in firms (Working Paper, Arizona State University).

Nelson, R. R., \& Winter, S. G. (1982). An evolutionary theory of economic change. New York: McGraw-Hill.

Nemec, C. R. (1995). Executive plurality: Relationship with firm financial performance, external regulations, and the role of the board of directors (Unpublished dissertation, Southern Illinois University, Carbondale, IL). 
Ocasio, W. (1999). Institutionalized action and corporate governance: The reliance on rules of CEO succession. Administrative Science Quarterly, 44, 384-416.

Parrino, R. (1997). CEO tumover and outside succession: A cross sectional analysis. Journal of Financial Economics, 46 (2), 165-197.

Sen, A. (1970). Collective choice and social welfare. San Francisco: Holden-Day Publishers.

Shen, W., \& Cannella, A.A. (2002). Power dynamics within top management and their impacts on CEO dismissal followed by inside succession. Academy of Management Journal, 45, 1195-1206.

Shen, W., \& Cannella Jr., A. A. (2003). Will succession planning increase shareholder wealth? Evidence from investor reactions to relay CEO successions. Strategic Management Journal, 24, 191-198.

Vancil, R. M. (1987). Passing the baton. Boston: Harvard University Press.

Worrell, D. L., \& Davidson III, W. N. (1987). The effects of CEO succession on stockholder wealth in large firms following the death of the predecessor. Joumal of Management, $13,509-515$.

Wortell, D. L., Davidson III, W. N., Chandy, P. R., \& Garrison, S. (1986). Management turnover through deaths of key executives: Effects on investor wealth. Academy of Management Joumal, 29, 674-694.

Zhang, Y., \& Rajagopalan, N. (2004). When the known devil is better than an unknown god: An empirical study of the antecedents and consequences of relay CEO successions. Academy of Management Joumal, 47, 483-500.

Zucker, L. G. (1977). The role of institutionalization in cultural persistence. American Sociological Review; 42, 726-743.

Wallace N. Davidson III is the Henry Rehn Research Professor of Finance at Southern Illinois University at Carbondale. His research interests include corporate governance and control and executive succession. He has published in the Academy of Management Journal, Strategic Management Journal, The Journal of Finance, The Journal of Financial and Quantitative Analysis, and Financial Management, among others.

Shenghui Tong is Assistant Professor of Finance at Siena College. He got his Ph.D. in Finance from Southern Illinois University Carbondale in 2004. His research interests include corporate governance and control. 
Dan L. Worrell is Dean and Sam M. Walton Leadership Chair for the Walton College of Business at the University of Arkansas, Fayetteville. Dan received his Ph.D. from Louisiana State University in management. His research interests include an investigation of the antecedents and consequences of major organizational events involving key executives. He has published in the Academy of Management Journal, Strategic Management Journal, and Journal of Management, among others.

Wei Rowe is Associate Professor of Finance at the University of Nebraska - Omaha. She has done research in the areas of corporate governance, mutual funds, and Chinese financial market and economy. Her work has appeared in academic journals such as Financial Review, International Journal of Finance, Journal of Corporate Ownership and Control, and China Economic Review, among others. She is a member of American Finance Association and serves on the editorial board of ASBBS E-Journal. 
